\title{
Enhancement of Biogas Production from Rice Husk by $\mathrm{NaOH}$ and Enzyme Pretreatment
}

\author{
Syafrudin ${ }^{1, *}$, Winardi Dwi Nugraha ${ }^{1}$,Shandy Sarima Agnesia ${ }^{1}$, Hashfi Hawali Abdul Matin $^{2}$, and Budiyono ${ }^{3}$ \\ ${ }^{1}$ Department of Environmental Engineering, Faculty of Engineering, Diponegoro University, Semarang - Indonesia \\ ${ }^{2}$ Master Program of Environmental Science, School of Postgraduate Studies, Diponegoro Univers ity, Semarang - Indonesia \\ ${ }^{3}$ Department of Chemical Engineering, Faculty of Engineering, Diponegoro Univers ity, Semarang - Indonesia
}

\begin{abstract}
Biogas is a renewable energy source that can be used as an alternative fuel to replace fossil fuel such as oil and natural gas. This research aims to analyze the impact of $\mathrm{NaOH}$ (Sodium hydroxide) and enzyme usage on the production of rice husk biogas using Solid State Anaerobic Digestion (SS-AD). Generally, SS-AD occurs at solid concentrations higher than $15 \%$. The waste of rice husk are used as substrate with a $\mathrm{C} / \mathrm{N}$ ratio of $25 \%$ and the total of solid that are used is $21 \%$. Rice husk contains high lignin, therefore it is handled with chemical and biological treatment. The chemical preliminary treatment was using $\mathrm{NaOH}$ with various concentrations from $3 \%, 6 \%$ and $9 \%$ while the biological preliminary treatment was using enzyme with various concentration from $5 \%, 8 \%$, and $11 \%$. The biogas that is produced then measured every two days during 60 days of research with the biogas volume as a parameter observed. The result of the research shows that preliminary treatment with $\mathrm{NaOH}$ and enzyme can increase the production of biogas. The highest biogas production was obtained by the $\mathrm{NaOH}$ pretreatment using $6 \% \mathrm{NaOH}$ which was $497 \mathrm{ml}$ and by enzyme pretreatment using 11\% enzyme which was 667,5 ml.
\end{abstract}

\section{Introduction}

Energy has become a principal needs to modern society nowadays The need of energy use is increasing along with population growth and the increasing consumption of society, as they use a wide range of tools and equipment to ease their life [1]. Nationally, the utilization of energy is still dominated by conventional energy sources, which are non-renewable energy such as crude oil, coal, and natural gas The contribution of non renewable energy for the national power plants has reached $85 \%$ [2]. One of the ways to save oil fuel and other unrenewable energy is to find another alternative that can be renewable [3]. That is why, to lessen the dependency for oil fuel, the government has established the presidential decree of Republic of Indonesia number 5 year 2006 on the issue of developing an alternative energy source as a replacement of fuel oil, microbial consortium and pretreatment. That policy highlights on the matter of energy source that can be renewable as an alternative to fossil fuel.

Biogas is a renewable energy that is able to be used as an alternative fuel to replace fuels that are originated from fossil such as petrol and natural gas [4]. Biogas is also one of a bioenergy that could be define as a gas that is released when organic materials such as human waste, manure, straw, rice husk and leaves from sorted out vegetables that are fermented or under a process called methanisation [5]
Indonesia can be considered as a country with the richest biomass yet has a low utilization of biomass potential [6]. Rice husk consists of organic elements such as cellulose, hemicellulose, and lignin [7]. The decomposition of organic material that contains cellulose, hemicellulose, and lignin transpire slowly. Thus, to fasten the degradation process of organic material that contains, the pretreatment of basic materials is necessary to occur [8].

Chemical pretreatment process can be done by using $\mathrm{NaOH}, \mathrm{KOH}$, calcium, and other types of alcalines, From those three alcaline type $(\mathrm{NaOH}, \mathrm{KOH}$ and calcium) that have been tested for rice husk pretreatment, $\mathrm{NaOH}$ is the most effective to deprive lignin from the production of biogas[9]. This process is usually known as the delignification, which is the release of lignin from a complex compound.

The biologically pretreatment process with the help of microorganisms could also be used to process lingo cellulose and increase enzymeatic hydrolysis. Biological pretreatment for the increase of biogas production on $\mathrm{AD}$ included fungus pretreatment microbial consortium pretreatment and enzymeatic pretreatment [10].

\section{Methods}

This research is an experimental laboratory research. This research was done at a waste treatment laboratory, chemical engineering, University of Dipenegoro from December 2016 to February 2017.

\footnotetext{
* Corresponding author: udin syaf@yahoo.com
} 


\subsection{Test of rice husk TS contents}

Analysis of Total Solid (TS) with the standard method of APHA

- Chemical cup is dried on $103-105^{\circ} \mathrm{C}$ temperatures for 1 hour, chilled and then stored in a desiccators until the chemical cup is going to be used

- The chemical cup's weigh is being measured and noted

- Insert 25-50 g sample to the chemical cup and then weigh, after that dried inside an oven at $103-105^{\circ} \mathrm{C}$ for 1 hour

- The samples that have been dried afterwards are cooled on the desiccators later weighed until its heaviness decreased on the amount of $4 \%$ or $50 \mathrm{mg}$

$$
\% \text { Total solids }=\frac{(A-B) \times 100 \%}{C-B}
$$

Note:

A $=$ The weight of samples that have been

dried + chemical cup (mg)

$\mathrm{B}=$ The weight of chemical cup (mg)

$\mathrm{C}=$ The weight of wet sample + chemical cup (mg)

\subsection{Stage of Research}

\subsubsection{Preparation Stage}

- Tools are prepared and planned in line with the variable of the research

- Take rice husks to be weighed and put into the vessel as many as the amount of the variable (14 variables)

- Do pretreatment to each corresponding variable

\subsubsection{The Operation Stage}

- Put rice husks and cow's rumen inside the biodigester with each biodigester filled with both rice husks and cow's rumens that are in line with determined variation

- Put the micronutrients as needed

- Input water into the biodigester

- Wait on the fermentation process until the biogas is formed

- Measure the volume of newly formed biogas every two days so that the biogas doesn't regenerated.

\section{Result and Discussion}

\subsection{Pretreatment $\mathrm{NaOH}$}

In this research, the concentration variations that were used as a chemical pretreatment were the amount of $3 \%$, $6 \%$ and $9 \%$. This research aims to analyze the impact of $\mathrm{NaOH}$ on rice husks in biogas production using SS-AD methods. The data of biogas volume were presented as a daily cumulative biogas yield during 60 days of research, as seen on Figure 1.

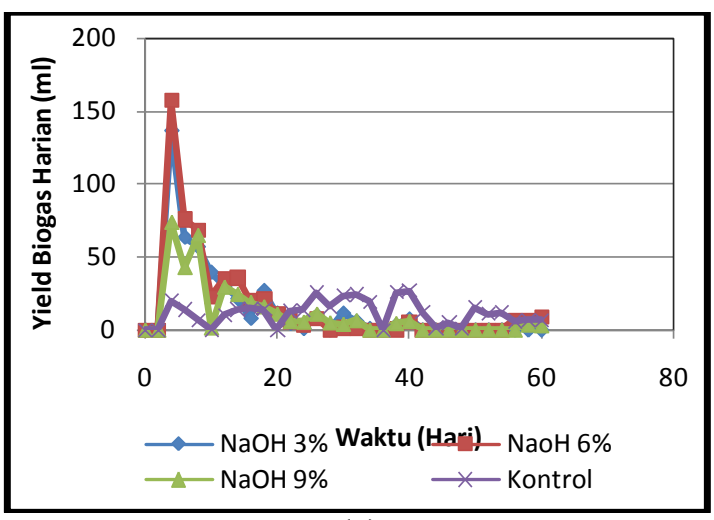

(a)

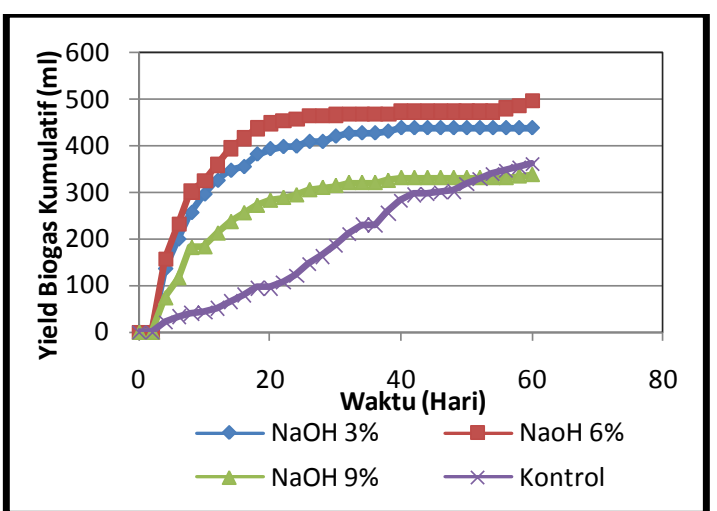

(b)

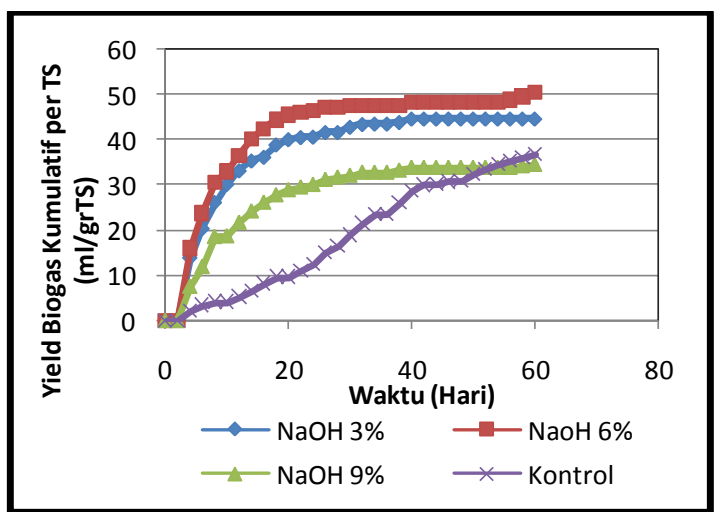

(c)

Fig. 1. The Impact of $\mathrm{NaOH}$ to Biogas Production

Figure1 (a) shows the $6 \%$ increase of $\mathrm{NaOH}$, and at the measuring session on day 2 it reached the highest peak with the amount of $152 \mathrm{ml}$ and $163 \mathrm{ml}$. The average daily biogas yield reached $157,5 \mathrm{ml}$. Then, on the next day of research the biogas production declined gradually. However, with a $6 \% \mathrm{NaOH}$ reactor, it produced biogas yield again on the 56th, 58th and 60th day. Each with the amount of $6,5 \mathrm{ml}, 7 \mathrm{ml}$, and $9 \mathrm{ml}$.

Figure1 (b) shows the impact of $\mathrm{NaOH}$ pretreatment on cumulative biogas production. Result showed that the reactor with $6 \% \mathrm{NaOH}$ produce the highest biogas yield of $497 \mathrm{ml}$. Whereas, $3 \%$ and $9 \%$ concentrations of $\mathrm{NaOH}$ resulted 439 and 338,5 biogas yields. Whilst, a reactor that wasn't apply with pretreatment, resulted $361,5 \mathrm{ml}$ biogas. 
Figure 1 (c) shows cumulative biogas yield per TS unit result as the impact of using $\mathrm{NaOH}$. The highest number of cumulative biogas yield per TS unit was resulted by a reactor filled with $6 \% \mathrm{NaOH}$ which was $50,60 \mathrm{ml} / \mathrm{gr}$ TS. Furthermore, $3 \% \mathrm{NaOH}$ resulted 44,70 $\mathrm{ml} / \mathrm{gr} \mathrm{TS}$, while $9 \% \mathrm{NaOH}$ and control reactor gave confiding result of $34,46 \mathrm{ml} / \mathrm{gr}$ and $36,81 \mathrm{ml} / \mathrm{gr}$ TS.

These sequence of elucidations showed that biogas yield increased after preliminary treatment with added $\mathrm{NaOH}$ and enzyme was done This points out that doing chemical and biological pretreatments influence biogas production significantly.

Whilst, for other reactors such as 3\% and 9\% each also used 5\% enzyme, resulted $44,70 \mathrm{ml} / \mathrm{gr}$ TS and $34,46 \mathrm{ml} / \mathrm{gr}$ TS This states that the usage of $6 \% \mathrm{NaOH}$ as a chemical pretreatment for rise husk wastes produce the most optimal biogas yield, compare with $3 \%$ and $9 \%$ $\mathrm{NaOH}$. According to the research of $\mathrm{He}$ et al said that the utilization of $6 \% \mathrm{NaOH}$ is the optimal dose for a pretreatment of rise husk [11]. The utilization of $6 \%$ $\mathrm{NaOH}$ on rice husks wastes indicated the increasing biogas production with the amount of $27,3-64,5 \%$ than the ones that were not using $\mathrm{NaOH}$. Hosseini et al reported that with the increasing of sodium hydroxide $(\mathrm{NaOH})$ from 15 to $30 \mathrm{gr} / \mathrm{L}$ it increased the rice stras biodegradability and so it also increased the production of biogas[12].

The usage of $\mathrm{NaOH}$ on pretreatment basically is a process of delignification that cause lignin to dissolved in a massive amount. Nevertheless, too much usage of $\mathrm{NaOH}$ will allow a high alkali atmosphere to substrate. Thus it will disturb the microorganisms's activity [13]. The application of $9 \% \mathrm{NaOH}$ produced the lowest result of biogas yield than the ones without pretreatment. This shows that $9 \% \mathrm{NaOH}$ does not increases biogas result on rice husks, This is because $9 \% \mathrm{NaOH}$ gives alkali atmosphere to the reactor which influence the activity of microorganism.

\subsection{Pretreatment Enzyme}

In this research the concentration variation of enzyme that was used as a biological pretreatment were $5 \%, 8 \%$ and $11 \%$. This research aims to analyze the impact of enzyme on rice husks in biogas production using SS-AD methods. The data of biogas volume are presented as a daily cumulative biogas yield during 60 days of research, as seen on Figure 2.

Figure 2 (a) shows the difference of daily biogas yield on rice husks that were on biological pretreatment with variety of enzyme amount such as $5 \%, 8 \%$, and $11 \%$, each also was given chemical pretreatments using $3 \%$ of $\mathrm{NaOH}$ and compared to the ones that didn't have chemical or biological pretreatments. Reactor that had $11 \%$ enzyme addition, on the 4th day of measure, the $11 \%$ enzyme reactor reach the highest number of $256 \mathrm{ml}$ and $289 \mathrm{ml}$ with biogas yield daily average production is $272,5 \% \mathrm{ml}$. Moreover, on the next day of research, the biogas production decreased. Reactor 2 with $11 \%$ enzyme produced yield biogas again on the 56th and 58th days each with the amount of $21 \mathrm{ml}$ and $14 \mathrm{ml}$.

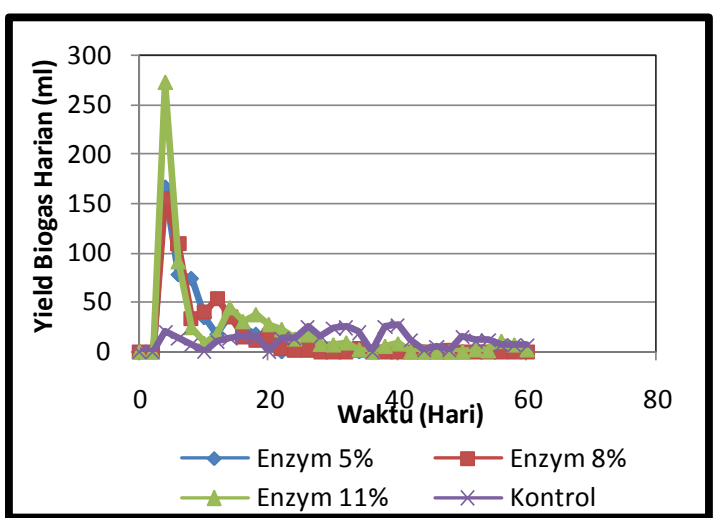

(a)

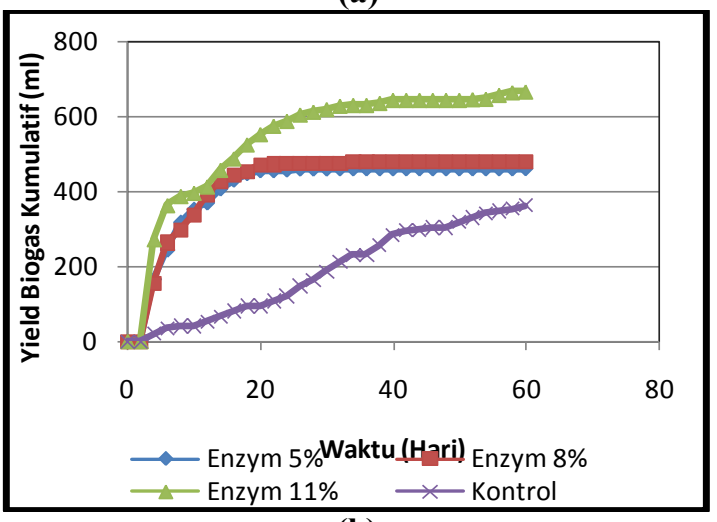

(b)

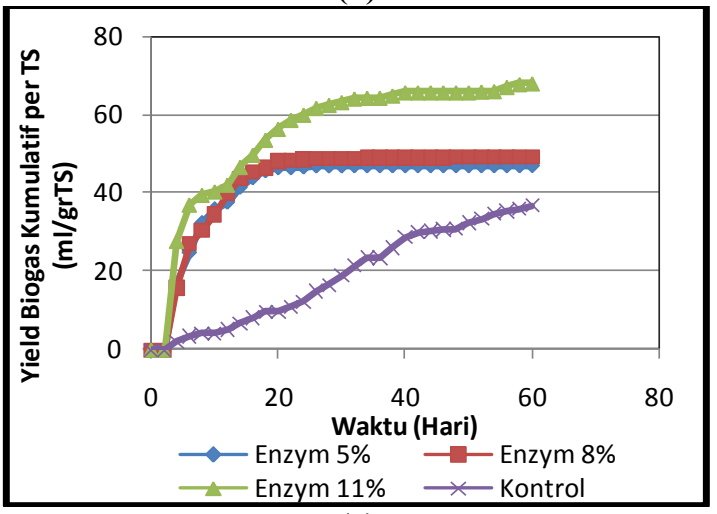

(c)

Fig. 2. The Impact of $\mathrm{NaOH}$ to Biogas Production

Figure2 (b) shows the influence of enzyme pretreatment on the cumulative biogas production. Result showed that reactor that had $11 \%$ enzyme generated the highest biogas yield which was $667,5 \%$ $\mathrm{ml}$. Whereas with a $5 \%$ and $8 \%$ enzyme concentrations each generated $462 \mathrm{ml}$ and $480,5 \mathrm{ml}$ biogas yields. While reactor that was not given pretreatment, resulted $361,5 \mathrm{ml}$ biogas

Figure 2 (c) shows the production of biogas yield cumulative result per TS unit on the influence of enzyme on the biogas production on rice husk. The highest biogas yield cumulative result per TS unit was generated by reactor filled with $11 \%$ enzyme with the amount of $67,96 \mathrm{ml} / \mathrm{gr}$ TS. Moreover, for $5 \%$ and $8 \%$ enzyme each produced each 47, $04 \mathrm{ml} / \mathrm{gr}$ TS and 48,92 $\mathrm{ml} / \mathrm{gr} \mathrm{TS}$, while the control reactor produced $36,81 \mathrm{ml} / \mathrm{gr}$ TS biogas. 
Those series of explanations indicated that the biogas yield increased after the preliminary treatment using addition of enzyme and $\mathrm{NaOH}$. On a reactor that used $11 \%$ enzyme and $3 \% \mathrm{NaOH}$ resulted the highest biogas yield which was $67,96 \mathrm{ml} / \mathrm{gr}$ TS. Whilst for control reactor that didn't use enzyme or $\mathrm{NaOH}$ produced biogas yield of $36,81 \mathrm{ml} / \mathrm{gr}$ TS.

Other reactors that used $5 \%$ and $8 \%$ enzyme, both used $3 \%$ of $\mathrm{NaOH}$ and generated $47,04 \mathrm{ml} / \mathrm{gr}$ TS and $48,92 \mathrm{ml} / \mathrm{gr}$ TS. This confirms that the usage of $11 \%$ as a biological pretreatment for rice husks waste generated the most optimal biogas yield compares $5 \%$ and $8 \%$ enzyme.

Zhang et al. (2011) used tapioca dregs and did a microbial consortium pretreatment in a batch reactor with $55 \mathrm{oC}$ temperature could result methane yield of $259,46 \mathrm{~mL} / \mathrm{g}$ VS this was obtainable on 12 hours of preliminary treatment where $96,63 \%$ was higher than control which was $131,95 \mathrm{~mL} / \mathrm{g}$ VS) [14].This proofs that the use of microbial consortium on rice husks waste pretreatment can help degrade lignocellulose so the production of biogas is increased.

On the $11 \%$ enzyme research showed the best concentration on increasing biogas production rather than $5 \%$ and $8 \%$ enzyme. The reactor that was filed with $5 \%$ enzyme, it resulted the lowest biogas between $8 \%$ and $11 \%$ enzyme, This is in line with what Purwoko et al. had researched which stated that the higher the utilization of microbial consortium with EM4 trademark then the higher the biogas production will increased [15].

\subsection{The production rate of biogas from rice husks}

In this research the objective is to analyze the production rate of biogas on rice husk wastes using SS-AD method. The data that were obtained then were solved in a numerical way with regression non linear using Polymath 6.0. Polymath 6.0 will gained biogas production rate constants $(\mathrm{U})$, maximum production of biogas (A), and the minimum time of biogas creation $(\lambda)$.

\subsubsection{Production on the effect of $\mathrm{NaOH}$}

Table 1 and Figure 3 show that the usage of $6 \% \mathrm{NaOH}$ has given a real impact on the kinetic constant of biogas production. From the Polymath 6.0 result, $6 \% \mathrm{NaOH}$ has the highest production rate compares to $3 \% \mathrm{NaOH}$, $9 \% \mathrm{NaOH}$, and control. The kinetic constant of $6 \%$ $\mathrm{NaOH}$ is avowed as the constant production rate of biogas rate (U), maximum biogas production (A), and the minimum time of biogas formation $(\square)$ each with a value of 3,97 ml/(gr TS per days), 48,06 ml/gr TS; and 0,75 per days. This means that rice husks that were treated with $6 \% \mathrm{NaOH}$ pretreatment had a production rate constant of $3,97 \mathrm{ml} /$ (gr TS days) resulting biogas production of 48,06 $\mathrm{ml} / \mathrm{gr}$ TS and produce the first time on the 0,75 day.

The result of biogas yield with $6 \%$ pretreatment generated the highest biogas yield compared to 3\%
$\mathrm{NaOH}$ and $9 \% \mathrm{NaOH}$ and control. The $3 \% \mathrm{NaOH}$ had second order of biogas yield and biogas rate production each on the amount of $3,22 \mathrm{ml} / \mathrm{gr}$ TS and $43,77 \mathrm{ml} /(\mathrm{gr}$ TS days) with the initial formation of biogas on the 0,46 day. Further, $9 \% \mathrm{NaOH}$ had the lowest biogas which was $33,44 \mathrm{ml} / \mathrm{gr}$ and biogas production rate of 1,97 $\mathrm{ml} /$ (gr TS days) with the initial formation of biogas on the 0,47 day. On the other hand, reactor without pretreatment (control) had a biogas yield of 43,32 ml/gr TS and the lowest production rate which was 0,78 $\mathrm{ml} /$ (gr TS days) with the longest initial formation of biogas on the 7,83 days. This showed that the usage of $9 \% \mathrm{NaOH}$ on rice husks caused lower biogas yield compares to rice husks that didn't have preliminary treatment.

Table 1.Kinetic constant in effect variation $\mathrm{NaOH}$

\begin{tabular}{|l|c|c|c|c|}
\hline \multicolumn{1}{|c|}{ Constant } & $\begin{array}{c}\mathbf{N a O H} \\
\mathbf{3 \%}\end{array}$ & $\begin{array}{c}\mathbf{N a O H} \\
\mathbf{6 \%}\end{array}$ & $\begin{array}{c}\mathbf{N a O H} \\
\mathbf{9 \%}\end{array}$ & Control \\
\hline $\mathrm{A}, \mathrm{ml} / \mathrm{gr} \mathrm{TS}$ & 43,77 & 48,06 & 33,44 & 43,32 \\
\hline $\begin{array}{l}\mathrm{U}, \mathrm{ml} /(\mathrm{gr} \mathrm{TS} \\
\text { day) }\end{array}$ & 3,22 & 3,97 & 1,97 & 0,87 \\
\hline$\lambda$, day & 0,46 & 0,75 & 0,47 & 7,83 \\
\hline
\end{tabular}

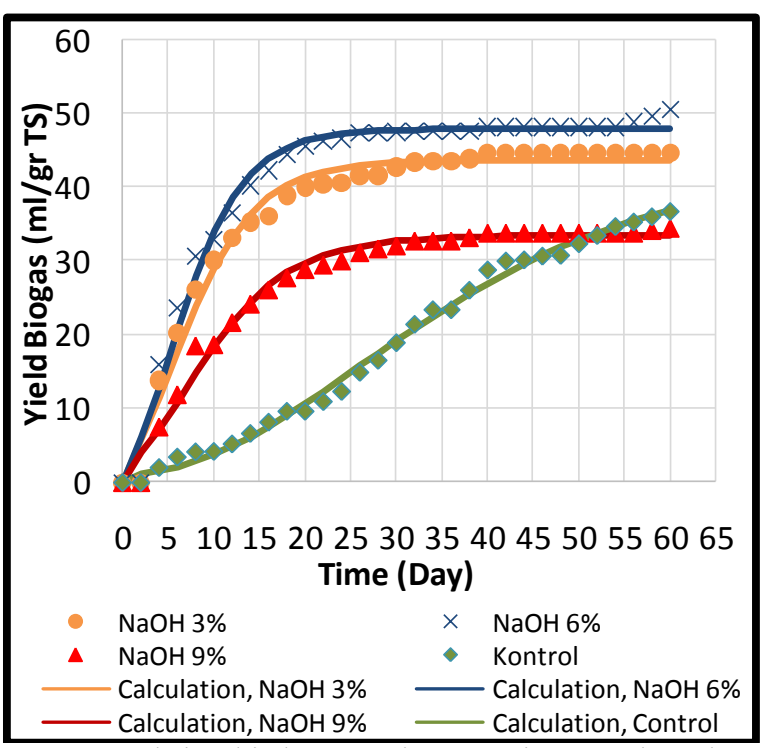

Fig. 3. Relationship between data experiment and results calculation on effect variation $\mathrm{NaOH}$

From the data above, it can be concluded that the usage of $3 \% \mathrm{NaOH}$ and $6 \% \mathrm{NaOH}$ resulted biogas yield that was higher than the pretreatment (control) ones with faster production rate and faster biogas formation time. Moreover, the concentration variation of $6 \% \mathrm{NaOH}$ gave the highest biogas yield of 48,06 biogas $\mathrm{ml} / \mathrm{gr} \mathrm{TS}$, $6 \% \mathrm{NaOH}$ had the highest rate production compare to $3 \% \mathrm{NaOH}$ and $9 \% \mathrm{NaOH}$ and control which is 3,97 $\mathrm{ml} /$ (gr TS day). This is because the $11 \% \mathrm{NaOH}$ reactor biogas result is constant.

Figure 4 shows the calculation from the biogas result and $6 \% \mathrm{NaOH}$ using Polymath 6.0. Thus, the maximum of biogas yield production can be found and the termination time of biogas production. 


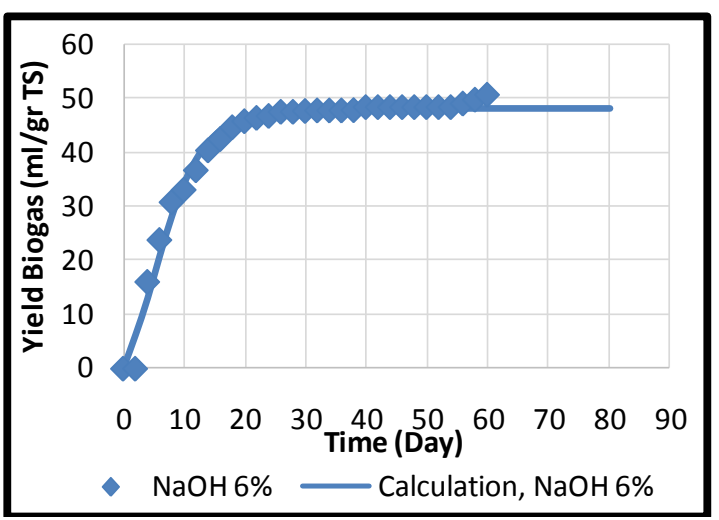

Fig. 4. Data Calculation results on the effect $\mathrm{NaOH} 6 \%$

Based on Figure 4, it can be seen that the biogas yield maximum on $6 \% \mathrm{NaOH}$ was $48,06 \mathrm{ml} / \mathrm{gr}$ TS and this was reached on the 50th day. This demonstrates the rice husks biogas with $6 \% \mathrm{NaOH}$ is stable and can not result any more biogas. As seen from the data in the 50th day the biogas production has stopped. This phenomenon can be used to design SS-AD biodigester from rice husk with the continuation of $\mathrm{NaOH}$ preliminary treatment during 50 days.

Once the modeling preliminary treatment was done, by adding $6 \%$ of $\mathrm{NaOH}$, then $48,06 \mathrm{ml} / \mathrm{grTS}$ biogas yield was gained. When there are 1 ton rice husks wastes, thus those can result biogas as much as $48.060 .000 \mathrm{ml}$ or $48,06 \mathrm{~m} 3$. If this is converted to other form of energy, then it will result $1 \mathrm{~m} 3$ biogas equals with $4,7 \mathrm{kWh}$ so the electrical energy generated by $225,88 \mathrm{kWh}$. According PT. PLN (Persero) if the potential of electric energy is converted into electricity cost in March 2017 for Rp. $1.467,28 / \mathrm{kWh}$, then the cost can be reduced to Rp. $331.432,1$.

This can turn on the lights with 60-100 watt of power for 303 hours, can also run motor for $1 \mathrm{hp}$ for 101 hour and produce $237,82 \mathrm{kwh}$ amount of electricity.

\subsubsection{Production on the effect of enzyme}

Table 2 and Figure 5 indicates that $11 \%$ enzyme application gave real influence to the kinetic constants of biogas production. From the polymath result $5 \%$ enzyme had the highest rate of biogas production compared to $8 \%$ enzyme and $11 \%$ enzyme, and control. Kinetic constant of $5 \%$ enzyme declared as a constant rate of biogas rate production $(\mathrm{U})$, maximum biogas production (A), and the maximum time of biogas creation ( $\square$ ) each on the value of $4,78 \mathrm{ml} /$ (gr TS day), $46,80 \mathrm{ml} / \mathrm{gr}$ TS; and 1,16 day. This means that rice husk that had been given $5 \%$ enzyme pretreatment had constant rate of 4,78 $\mathrm{ml} /$ (gr TS day) with maximum biogas production result of $46,80 \mathrm{ml} / \mathrm{gr}$ TS delivered biogas for the first time on the 1,16 day.

In the biogas yield results with $11 \%$ pretreatment performed produced the highest biogas yield compared with $5 \%$ enzymes, $8 \%$ enzymes, and control. $11 \%$ enzyme reactor had the highest biogas yield which was $64.86 \mathrm{ml} / \mathrm{g} \mathrm{TS}$ and was the lowest biogas production rate compared with the $5 \%$ and $8 \%$ enzyme which was 3.80 $\mathrm{ml} /$ (gTS-day) with the initial formation of biogas at day 0.99 . In the enzyme reactor of $5 \%$, it had the lowest biogas yield of $46.80 \mathrm{ml} / \mathrm{g}$ TS and the highest biogas production rate of $4.78 \mathrm{ml} /(\mathrm{g}$ TS-day) with the initial formation of biogas on the 1.16 day. In the enzyme reactor of $8 \%$, it had a higher biogas yield than the yield of biogas enzyme $5 \%$ on the amount of $64.96 \mathrm{ml} / \mathrm{g}$ TS and a faster production rate compared with $11 \%$ enzyme that was $4.63 \mathrm{ml} /(\mathrm{g}$ TS-day $)$ with the initial the formation of biogas on 1.13 day. While the reactor without pretreatment (control), had the lowest biogas yield of $43.32 \mathrm{ml} / \mathrm{g}$ TS and the lowest biogas production rate of $0.78 \mathrm{ml} /(\mathrm{g}$ TS-day) with the initial formation of biogas longest on the day 7.83 .

Table 2.Kinetic constant in effect variation enzyme

\begin{tabular}{|l|c|c|c|c|}
\hline \multicolumn{1}{|c|}{ Constant } & $\begin{array}{c}\text { Enzyme } \\
\mathbf{5 \%}\end{array}$ & $\begin{array}{c}\text { Enzyme } \\
\mathbf{8 \%}\end{array}$ & $\begin{array}{c}\text { Enzyme } \\
\mathbf{1 1 \%}\end{array}$ & Control \\
\hline A, ml/gr TS & 45,05 & 43,72 & 64,86 & 42,55 \\
\hline $\begin{array}{l}\text { U, ml/(gr TS } \\
\text { day) }\end{array}$ & 4,42 & 3,99 & 3,80 & 0,87 \\
\hline$\lambda$, day & 1,31 & 1,51 & 0,99 & 7,83 \\
\hline
\end{tabular}

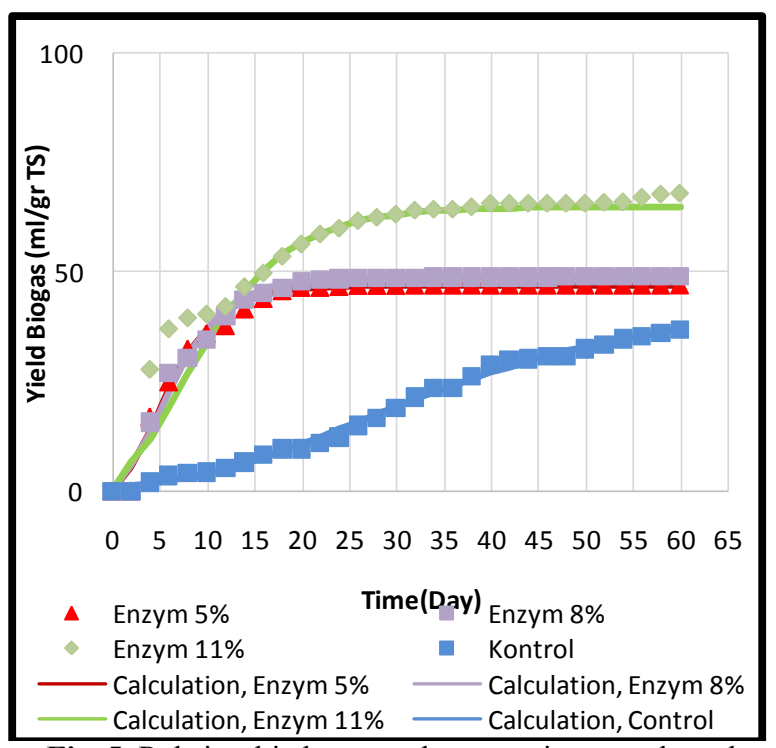

Fig. 5. Relationship between data experiment and results calculation on effect variation enzyme

From the data above it can be concluded that the use of variety of enzyme produce biogas yield higher than without pretreatment (control) with a faster production rate and faster time formed of biogas. Furthermore, the variation of enzyme concentration of $11 \%$ gave the highest biogas yield of $64.96 \mathrm{ml} /(\mathrm{g}$ TS). At $11 \%$ the enzyme reactor had the lowest production rate compared with the $5 \%$ and $8 \%$, enzyme which was $3.80 \mathrm{ml} /(\mathrm{g}$ TSday). This was because the enzyme reactor $11 \%$ still produced biogas at the longest period of time until the 60th day so that the biogas was neither stable nor constant.

Figure 6 shows the calculation results of the enzyme $5 \%$ biogas using Polymath 6.0 so the maximum yield of 
biogas which can be produced and the termination time to produce biogas.

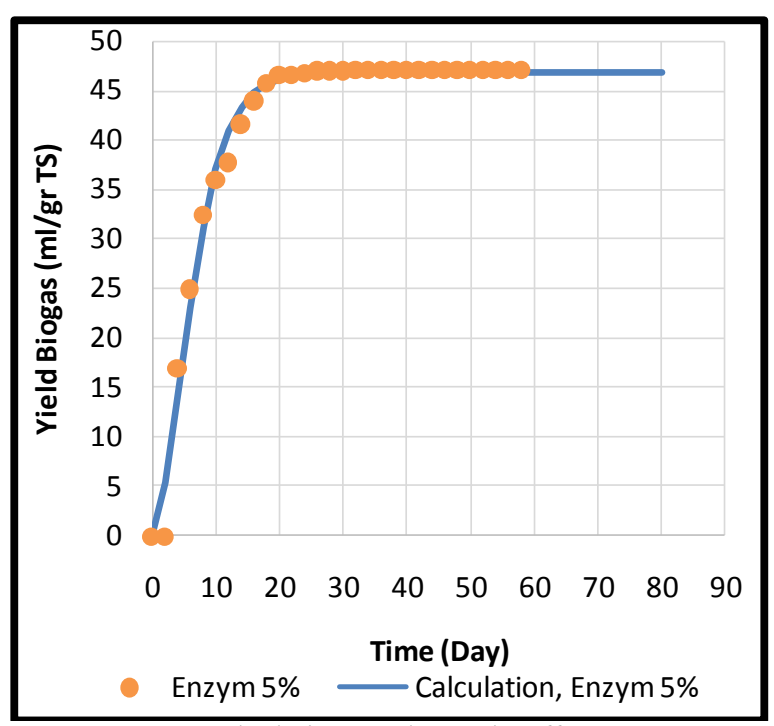

Fig. 6. Data calculation results on the effect enzyme 5\%

Based on the data in Figure 7 it can be seen that the maximum biogas yield on the $5 \%$ enzyme was 46.80 $\mathrm{ml} / \mathrm{g}$ TS can be achieved on the 36th day. This shows that the results of biogas from waste rice husks that had enzyme pretreatment of $5 \%$ is likely to be stable and does not produce more biogas. From the data it also can be acknowledged hat on the 36th day basically biogas production has stopped. This could be used to design biodigester SS-AD from rice husk with a continuous enzyme pre-treatment with a residence time of 36 days.

Once the modeling on the preliminary treatment is done, with adding $5 \%$ then $46,80 \mathrm{ml} / \mathrm{gr}$ TS biogas is obtained. When there are rice husks wastes as much as 1 ton, it can result to $46.800 .000 \mathrm{ml}$ or $46,80 \mathrm{~m} 3$ biogas. If it is converted into another form of energy, it will gained $1 \mathrm{~m} 3$ biogas equals with $4,7 \mathrm{kWh}$ so the electrical energy generated by $219,96 \mathrm{kWh}$. According PT. PLN (Persero) if the potential of electric energy is converted into electricity cost in March 2017 for Rp. $1.467,28 / \mathrm{kWh}$, then the cost can be reduced to Rp. $332.742,91$.

\section{Conclusion}

The conclusions derived from this research are:

1. Pretreatment using three variation of $\mathrm{NaOH}$ can be concluded that, the usage of $6 \% \mathrm{NaOH}$ generated the highest biogas yield compares to $3 \% \mathrm{NaOH}$ and $9 \%$ $\mathrm{NaOH}$.

2. From three variation of enzyme pretreatment, can be concluded that the usage of $11 \%$ enzyme resulted the highest biogas yield compared to $5 \%$ and $8 \%$ enzyme.

3. The rate of biogas production with the resulted rate maximum which is $6 \% \mathrm{NaOH}$ with values as $\mathrm{A}, \mathrm{U}$, and $\lambda$ each with the amount of $48,06 \mathrm{ml} / \mathrm{gr}$ TS; 3,97 $\mathrm{ml} /$ (gr TS.days); and 0,75 day. On the other hand, for enzyme pretreatment, the maximum rate result on $5 \%$ enzyme condition with $A, U$, and $\lambda$ each on the amount of $46,80 \mathrm{ml} / \mathrm{gr} \mathrm{TS} ; 4,78 \mathrm{ml} /(\mathrm{gr}$ TS days); 1,16 day

\section{References}

1. Y. F.Saputri, T.Yuwono, and S.Mahmudsyah, Pemanfaatan Kotoran Sapi untuk Bahan Bakar PLT Biogas $80 \mathrm{KW}$ di Desa Babadan Kecamatan Ngajum Malang. 1-6 (2014)

2. E.Mufrizon, and P. Subekti, Kebijakan Energi Baruterbarukan Serta Peluang Pemanfaatan Biogas dan Biomasa Limbah Pengolahan Kelapa Sawit untuk Pembangkit Tenaga Listrik di Propinsi Riau(2013)

3. Febriyanita, Wahyu. Pengembangan Biogas Dalam Rangka Pemanfaatan Energi Terbarukan di Desa Jetak Kecamatan Getasan Kabupaten Semarang [Skripsi]. Semarang: Universitas Negeri Semarang (2015)

4. L.Houdkova, J. Boran., J. Pecek and P. Sumpela. Journal of Thermal Science 12(4) : 27 -33 (2008)

5. Ichsan, H. Hadiyanto and R. Hendroko. Energy Procedia. 47, 143-148 (2014)

6. Hasan M.H., Mahlia T.M.I., Nur H. A review on energy scenario and sustainable energy in Indonesia. May. Renew Sustain Energy Rev;16(4):2316-28 (2012)

7. H. W. Hsu, and B.S. Luh, Rice Hull. Rice Product And Utilization. Editor: Bor Shiun Luh. New York: Avi Publishing Company Inc. Hal. 736-740 (1980)

8. M. J. Taherzadeh, and Karimi, K. International Journal of Molecular Sci , 9, 1621-1651 (2008)

9. D. Yang, Y. Zheng, R. Zhang, In: An ASABE International Meeting, Reno, Nevada, USA, 21-24 June, American Society of Agricultural Engineers. Paper No.: 095685 (2009)

10. M. Tuomela, M. Vikman, A. Hatakka, and M. Itavaara, Bioresource Technology 72: 169-183 (2000)

11. Y. He, Y. Pang, Y. Liu, X. Li, K. Wang, Beijing: Departement of Enviromental Science and Engineering (2008)

12. S. M. Hosseini, H. A. Aziz, S. Meisam, V. Kiamahalleh, Urban Waters: resource or risks, Arcueil : France (2011)

13. M. Gunamantha, W. N. Yuningrat, Jurnal Sains dan Teknologi, Vol. 3, No.1 (2014)

14. Q. Zhang, J. He, M. Tian, Z. Mao, L. Tang, J. Zhang, Bioresour Technol Vol. 102:8899-906 (2011)

15. Purwoko, M. Romli, Suprihatin, L. Haditjaroko, Jurnal Teknologi Industri Pertanian, Vol. 26, No. 2, 134-142 (2016) 